dos entre as duas decadas. Alem disso, to-

ram realizadas entrevistas com dirigente e

professores de Centros Federais de Edyacação Tecnológica (Cefets) e de Escolas Técnicas. O material foi reunido e dividido em três partes, com 15 capítulos no lotal.

Buscando questões mais/amplas, da teoria e da história, a primeira parte carrega uma ambientação do estad $\varnothing$ da arte das políticas de expansão do ensino médio técnico e de fragmentação da educação profissional até à década de $\beta 0$. Na segunda parte, três capítulos expressam o movimento de travessia da socjedade, evidenciada pelo conflito de concepções e o jogo de forças que disputam/a direção da sociedade brasileira em todos os âmbitos. A parte três refere-se à década de 1990, com oito capítulos em que/se explicitam as mudanças na base matefial da produção com a tese da reestruturação produtiva, as reformas do Estado e as reformas educacionais, além de abordar a natureza da educação que forma

\section{Em busca de um modelo de universidade}

MOROSINI, Marília (Org.). A universidade no Brasil: concepções e modelos. Brasília: Instituto Nacional de Estudos e Pesquisas Educacionais Anísio Teixeira, 2006. 470 p.

Se no período histórico-social moderno a universidade tinha como essência a construção da narrativa totalizante, que pouca importância tem para as demandas políticas e culturais nos dias de hoje, a pós-moderna contesta o conhecimento global e reconhece a emergência de conhecimentos locais. Paradigmas estão sendo questionados e novos modelos estão sendo propostos. Com essa premissa, o livro A Universidade no Brasil: 
concepções e modelos busca responder a algumas questões fundamentais. Qual o modelo de universidade brasileira? Ou melhor, existe uma experiência brasileira de universidade? Como ela pode ser identificada e quais são os traços universais e específicos que essa experiência ensina?

O trabalho de pesquisa, dividido em 19 capítulos, foi realizado pela Rede Universitas, que reúne um grupo de pesquisadores e bolsistas de 17 instituições de ensino superior (IES) congregados no Grupo de Trabalho Política de Educação Superior da Associação Nacional de Pós-Graduação e Pesquisa em Educação. Como resultado, as 470 páginas da coletânea apresentam estudos sobre as instituições de educação superior brasileira que representam ou representaram a visão do País sobre a universidade.

A obra problematiza a experiência universitária no Brasil sob a ótica dos modelos "clássicos" de universidade, ou seja, o napoleônico ou profissional e o humboldtiano ou de pesquisa. Estão presentes, também, eventuais comparações com outras experiências latino-americanas e as experiências européia e norte-americana.

Os capítulos abrangem contextos sócio-econômico-político e cultural do nascimento das IES, estrutura organizacional, trajetória, desafios, financiamento, autonomia, avaliação, democratização, relação públicoprivado, entre outras abordagens. A obra está dividida em três partes interligadas: na primeira parte, os pesquisadores apresentam uma visão geral do sistema de educação superior no Brasil e a organização universitária; na segunda, são descritas e analisadas as universidades brasileiras congregadas em federais, confessionais-comunitárias e estaduais; e, finalmente, na parte três, um ensaio propõe uma análise integrada dos diversos modelos consubstanciados em IES e com os desafios de um modelo que considera a inovação.

A socióloga e doutora em Educação Marilia Morosini é a organizadora da coletânea. Ela também é pós-doutora junto ao LLILAS - Institute of Latin American Studies, da Universidade do Texas - Austin.

A edição conta também com os seguintes colaboradores: Afrânio Catani, doutor em Sociologia pela Faculdade de Filosofia, Letras e Ciências Humanas da USP; Ana Paula Hey, doutora em Educação, na área de Sociologia da Educação, pela UFSCar; Arlete Camargo, doutora em Educação pela UFMG;
Deise Mancebo, doutora em Educação pela PUC-SP, com pós-doutorado em Psicologia Social - USP; Dilvo Ristoff, diretor de Estatísticas e Avaliação da Educação Superior do Inep, doutor pela University of Southern California e pós-doutor pela University of North Carolina; Élcio Verçosa, doutor em História e Filosofia da Educação pela USP; Erasto Mendonça, doutor em Educação pela Unicamp, área de Política e Administração de Sistemas Educacionais; Helena Ibiapina Lima, doutora em Educação pela USP; João dos Reis Júnior, doutor em Educação pela PUC-SP e pós-doutor em Sociologia Política pela Unicamp; João Ferreira de Oliveira, doutor em Educação pela USP; Jorge Nicolas Audy, doutor em Administração pela PUCRS; Luciene Medeiros, mestre em Educação, Supervisão e Currículo; Luiz Fernando Dourado, doutor em Educação pela UFRJ; Maria das Graças Tavares, pedagoga e doutora em Educação Brasileira pela UFRJ; Maria de Lourdes Fávero, coordenadora do Proedes Programa de Estudos e Documentação e Sociedade; Maria do Carmo Peixoto, doutora em Educação pela UFRJ, diretora de Avaliação Institucional da UFMG; Maria Estela Dal Pai, doutora em Ciências Humanas pela UFRGS; Maria Helena Abrahão, doutora em Ciências Humanas-Educação pela UFRGS; Mariluce Bittar, doutora em Educação pela UFSCar; Olgaíses Maués, pedagoga, doutora pela Université Lille III, France, e pós-doutora em Educação pela Université Laval, Québec, Canadá; Otilia Seiffert, doutora em Psicologia da Educação pela PUC-SP; Regina Michelotto, doutora em Educação pela UFSCar e Università di Padova; Stela Meneghel, doutora em Políticas Educacionais pela Unicamp; Stella Cecília Segenreich, doutora em Educação pela UFRJ; Vera Lucia Chaves, socióloga, pedagoga, doutora em Educação pela UFMG; e Valdemar Sguissardi, doutor em Ciências da Educação pela Universidade de Paris - X (Nanterre).

\section{Aline Adolphs Consultora - Inep}

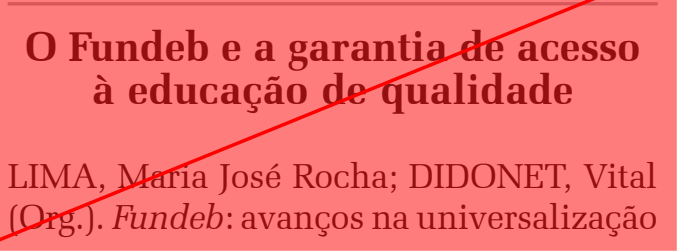

